\title{
Sınıf Öğretmenlerinin Öğrencilere Sundukları Sözel Problem Türleri*
}

\section{Types of Verbal Problems that Primary School Teachers' Present to Students}

\author{
H. Beyza CANBAZOĞLU**, Kamuran TARIM***
}

Öz: $\mathrm{Bu}$ çalışmanın amacı, sınıf öğretmenlerinin öğrencilere sundukları sözel problem türlerini belirlemektir. Çalışmada, karma yöntem araştırmaları modellerinden, yakınsayan paralel desen kullanılmıştır. Araştırmanın çalışma grubunu, Türkiye'nin güneyindeki bir ilin farklı okullarında görev yapan 104 sınıf öğretmeni oluşturmaktadır. Araştırmanın nicel verileri anket formu kullanılarak toplanmıştır. Araştırmanın nitel verileri ise "Görüş Alma Formu" kullanılarak elde edilmiştir. Nicel verilerin çözümlenmesinde betimsel istatistiklerden frekans ve yüzde dağılımları kullanılmıştır. Görüşmelerden elde edilen verilere ise içerik analizi yapılmıştır. Elde edilen bulgulara göre, sınıf öğretmenlerinin toplama ve çıkarmaya ilişkin en fazla sundukları problem türlerinin; birleştirme ve ayırma problemlerinden sonuç miktarının bilinmediği durumlar; parça-parça-bütün problemlerinden parçanın bilinmediği durumlar; karşılaştırma problemlerinden ise farkın bilinmediği durumlara yönelik problem türleri olduğu; çarpma ve bölmeye ilişkin en fazla sunulan problem türlerinin ise; eş-grup problemlerinden tekrarlı toplama adil paylaşım, ölçüm bölmesi ve tekrarlı çıkarma ile karşılaştırma problemlerinden çarpma türü problemler olduğu belirlenmiştir. Öğretmenlerin büyük çoğunluğu çocukların gelişim özelliklerini göz önünde bulundurarak çocuklara sözel problem türlerini sunduklarını ifade etmişlerdir. Bununla birlikte, bazı problem türlerine yer vermeme nedenlerine ilişkin görüşlerinde ise, çocukların gelişim özelliklerine ve yaşlarına uygun olmaması ile müfredatta belirtilen kazanımlarda yer almaması gerekçelerini kullanmışlardır.

Anahtar Kelimeler: Sözel problem türleri, sınıf öğretmeni, matematik öğretimi, ilkokul dönemi.

\begin{abstract}
The purpose of this study is to identify the types of verbal problems that primary school teachers' presentation to students. The study was conducted by using convergent parallel design, one of the mixed method research designs. The participants of the study consisted primary school teachers' working at public schools in the district of southern province in Turkey's. The quantitative data of the study were collected using a questionnaire. The qualitative data of the study was obtained by using the "Interview Form". Descriptive statistics, as frequency and percentage distributions, are used in the analysis of quantitative data. Content analysis was conducted on the data obtained from the interviews. The result of the research revealed that primary school teachers prepared for the children usually presented the problems with unknown results more and they ignored the other kinds of problems.
\end{abstract}

Keywords: Types of verbal problems, word problems, primary school teachers', mathematics education, elementary school.

\footnotetext{
* Bu çalışma Eylül 2017'de Muğla Sttk1 Koçman Üniversitesi'nde düzenlenen "II. Uluslararası Çağdaş Eğitim Araştırmaları" Kongresinde sözlü bildiri olarak sunulmuştur.

** Arş. Gör., Çukurova Üniversitesi, Eğitim Fakültesi, Adana-Türkiye, ORCID: 0000-0001-5596-5019, e-posta: beyza.cnbzg10@gmail.com

*** Prof. Dr., Çukurova Üniversitesi, Eğitim Fakültesi, Adana-Türkiye, ORCID: 0000-0002-2048- 5207,e-posta:

kamuran.tarim@gmail.com
} 


\section{Giriş}

İlkokul Matematik öğretim programı; problem çözebilen, problem çözme sürecinde kendi fikir ve akıl yürütme becerilerini ifade edebilen, başkalarının matematiksel akıl yürütme süreçlerindeki eksikleri görebilen, matematiğe ilişkin olumlu tutum ve alg1 geliştiren bireyler yetiştirilmesini hedeflemektedir (Milli Eğitim Bakanlığı, [MEB], 2017). Bireylerin matematiği daha iyi anlayabilmeleri ve matematiksel becerileri kazanabilmeleri için problem çözme önemli bir rol oynamaktadır (Yaman ve Dede, 2005). Bu bağlamda ilkokul dönemi matematik eğitiminin temel konularından biri olan toplama, çıkarma, çarpma ve bölme işlemlerinin, çocuklar tarafindan kavramsallaştırılabilmesi için sözel problemlerin önemli olduğu söylenebilir (Tarım ve Deretarla Gül, 2003).

Toplama, çıkarma, çarpma ve bölme işlemine yönelik sözel problemler farklı şekillerde sinıflandırılabilmektedir. Van de Walle, Karp ve Bay-Williams (2016), toplama ve çıkarmaya ilişkin problem türlerini "birleştirme, ayırma, parça-parça-bütün, karşılaştırma problemleri" şeklinde sınıflandırmışlardır. Çarpma ve bölmeye ilişkin problem türlerini ise; eş-grup problemleri: çarpma/parçalamalı bölme/ ölçüm bölmesi; karşılaştırma: çarpma/parçalamalı bölme/ölçüm bölmesi şeklinde gruplandırmaktadır.

Toplama ve çıkarma işlemine yönelik sözel problemler dört gruba ve bilinmeyen değişken türüne göre kategorilere ayrılmıştır (Van de Walle, Karp ve Bay-Williams, 2016).

Tablo1.

Toplama ve Çıkarmaya Yönelik Sözel Problem Türleri

\begin{tabular}{|c|c|c|}
\hline Sözel Problem Türleri & Kategoriler & Örnek Problemler \\
\hline \multirow[t]{6}{*}{ Birleştirme } & Sonuç Miktarının Bilinmediği & $6+4=?$ \\
\hline & Durumlar & \\
\hline & Başlangiç & $?+7=9$ \\
\hline & Bilinmediği Durumlar & \\
\hline & Değișim $\quad$ Miktarının & $5+?=12$ \\
\hline & Bilinmediği Durumlar & \\
\hline \multirow[t]{6}{*}{ Ayırma } & Sonuç Miktarının Bilinmediği & $8-4=?$ \\
\hline & Durumlar & \\
\hline & Başlangiç & $?-7=5$ \\
\hline & Bilinmediği Durumlar & \\
\hline & Değişim $\quad$ Miktarının & $15-?=6$ \\
\hline & Bilinmediği Durumlar & \\
\hline \multirow[t]{4}{*}{ Parça-Parça-Bütün } & Bütünün $\quad$ Bilinmediği & $3+5=?$ \\
\hline & Durumlar & \\
\hline & Bilinmediği & $3+?=8$ \\
\hline & Durumlar & \\
\hline \multirow[t]{5}{*}{ Karşılaştırma } & Farkın Bilinmediği Durumlar & $6-2=?$ \\
\hline & Büyük Çokluğun Bilinmediği & $5+4=?$ \\
\hline & Durumlar & \\
\hline & Küçük Çokluğun Bilinmediği & $6-3=?$ \\
\hline & Durumlar & \\
\hline
\end{tabular}

Çarpma ve bölme işlemine yönelik sözel problemler ise, iki gruba ve bilinmeyen değişken türüne göre kategorilere ayrılmıştır (Van de Walle, Karp ve Bay-Williams, 2016). 
Canbazoğlu ve Tarım

Tablo 2.

Çarpma ve Bölmeye Yönelik Sözel Problem Türleri

\begin{tabular}{|c|c|}
\hline Sözel Problem Türleri & Kategoriler \\
\hline Eş-Grup Problemleri (Çarpma) & Bütünün Bilinmediği Durumlar (Tekrarlı Toplama) \\
\hline & Bütünün Bilinmediği Durumlar (Oran) \\
\hline $\begin{array}{l}\text { Eş-Grup Problemleri } \quad \text { (Parçalamalı } \\
\text { Bölme) }\end{array}$ & $\begin{array}{l}\text { Grup Büyüklüğünün Bilinmediği Durumlar ( Adil } \\
\text { Paylaşım) }\end{array}$ \\
\hline & Grup Büyüklüğünün Bilinmediği Durumlar (Oran) \\
\hline Eş-Grup Problemleri (Ölçüm Bölmesi) & $\begin{array}{l}\text { Grup Sayısının Bilinmediği Durumlar (Tekrarlı } \\
\text { Cıkarma) }\end{array}$ \\
\hline & Grup Sayısının Bilinmediği Durumlar (Oran) \\
\hline Karşılaştırma Problemleri (Çarpma) & Çarpımın Bilinmediği Durumlar \\
\hline $\begin{array}{ll}\text { Karşılaştırma } & \text { Problemleri } \\
\text { (Parçalamalı Bölme) } & \end{array}$ & Grup Büyüklüğünün Bilinmediği Durumlar \\
\hline $\begin{array}{l}\text { Karşılaştırma } \\
\text { Bölmesi) }\end{array}$ & Çarpımın Bilinmediği Durumlar \\
\hline
\end{tabular}

Yapılan çalışmalar (Desli ve Loukidou, 2014; Olkun ve Toluk, 2002; Parmjit ve Teoh, 2010; Sarıbaş ve Aktaş Arnas, 2017; Singh, 2006; Tarım, 2017) yukarıda bahsedilen kategorilerin ders ve etkinlik kitaplarında çok sınırlı düzeyde yer verildiğini dolayısıyla çocukların çok sınırlı çeşitlilikteki problemlerle karşılaştığını göstermiştir. Olkun ve Toluk (2002) tarafindan yapılan çalışmada, Türkiye'de ilköğretim kitaplarında yer alan sözel problem türlerini belirlemek amaçlanmıştır. Elde edilen bulgulara göre, kitaplarda problem türlerinin hepsine yer verilmediği veya bazılarına çok az yer verildiği ortaya çıkmıştır. Tarım (2017) matematik ders kitaplarında öğrencilere sunulan problem türlerini incelediği çalışmasında MEB tarafindan hazırlanan ilkokul matematik ders ve öğrenci çalışma kitaplarında toplama ve çıkarmaya dayalı sözel problem türlerinde çoğunlukla sonuç bilinmeyenli problemlere yer verildiği, karşılaştırma problemlerine neredeyse hiç yer verilmediğini belirlemiştir.

Ögrencilerin sözel problem çözme ve kurma beceri ve yeterliliklerine sahip olmasında öğretmenin önemli bir rolü vardır. Öğretmenlerin matematiği etkili bir şekilde öğretme becerisi ve matematiksel bilgisi ile öğrenci başarısı üzerinde önemli etkisinin olduğunu ifade eden çalışmalar bulunmaktadır (Gonzalez Thompson, 1984; Hill, Rowan ve Ball, 2005; Swars, Hart, Smith, Smith ve Tolar 2007). Bu bağlamda öğrencilerin matematiksel bilgi ve beceriler konusunda yetkin olabilmesi için öncelikle öğretmenlerin yeterli matematiksel bilgi, beceri ve farkındalık düzeyinde olması gerektiği düşünülmektedir. $\mathrm{Bu}$ doğrultuda düşünüldügünde ögretmenlerin sözel problem türlerine yönelik bilgi, beceri ve farkındalıkların yüksek olması, bu becerileri sınıf ortamına aktarılması açısından önemlidir. Farkındalık düzeyi yüksek öğretmenlerin öğrencilerine tek düze sözel problem çalışmaları yaptırmak yerine sözel problem türlerinin birçoğuna yer vererek, öğrencilerinin üst bilişsel becerilerinin gelişmesine ve problem çözme süreçlerini kullanmasına katkı sağlayacağı düşünülebilir.

Çocukların sözel problem türlerini çözme becerilerinde başarılı olabilmeleri için, öğretmenler tarafindan sözel problem türlerinin hepsinin yeterli ölçüde çocuklara sunulması gerekmektedir (Nures ve Brgant, 2008; Sperry Smith, 2001; Van de Walle, Karp ve BayWilliams, 2016). Fakat yapılan çalışmalar, öğretmenlerin çocuklara sözel problemleri sunarken çoğunlukla sonuç bilinmeyenli problem türlerine yer verdiğini göstermektedir (Nures ve Brgant, 2008; Peterson, Fennema ve Carpenter, 1989). Sarıbaş ve Aktaş Arnas (2017) gerçekleştirdikleri çalışma ile okul öncesi ögretmenlerinin çocuklara hangi sözel problem türlerini sunduklarını belirlemeyi amaçlamışlardır. Elde edilen bulgular doğrultusunda, okul öncesi öğretmenlerinin çocuklara çoğunlukla sonuç bilinmeyenli problem türlerini sundukları belirlenmiştir. $\mathrm{Bu}$ bağlamda çocukların sözel problem çözme becerisinde yetkin duruma gelebilmeleri için bunları deneyimlemeleri önemlidir. Bu sebeple öğretmenler tarafından sınıf içi uygulamalarda bu 
problem türlerinin hepsine öğrencilerin bu alandaki becerilerini geliştirecek seviyede yer verilmesi gereklidir (Peterson, Fennema ve Carpenter, 1989).

Alan yazın incelendiğinde sadece okul öncesi döneminde sözel problem türlerinin çocuklara sunuluşunun incelendiği çalışmaların (Sarıbaş ve Aktaş Arnas, 2016; Sarıbaş ve Aktaş Arnas, 2017) olduğu görülmüştür. İlkokul düzeyinde ise sözel problem türlerinin ders ve etkinlik kitaplarında çocuklara sunuluşunun incelendiği çalışmalar (Desli ve Loukidou, 2014; Olkun ve Toluk, 2002; Parmjit ve Teoh, 2010; Singh, 2006; Tarım, 2017) olmasına rağmen öğretmenler tarafindan çocuklara sunuluşunun incelendiği çalışmanın olmadığı görülmüştür. Hâlbuki öğrencilerin ilk eğitim-öğretim yeri olan ilkokul, çocukların ilk temel becerileri ve düşünmeyi öğrenmeye başladığı süreçtir. Bu süreçte öğretmenlerin sınıf içi uygulamalarda öğrenciye sunduğu öğretim uygulamalarının ve çocuklara nasıl sunulduğunun önemli olduğu düşünülmektedir. Ancak matematik eğitim ve öğretiminde önemli rollerden biri olan sınıf öğretmenlerinin öğretim uygulamalarını ortaya koyan herhangi bir çalışmaya rastlanılmamıştır. $\mathrm{Bu}$ anlamda çalışmanın sınıf öğretmenleri ile yürütülmesi, sınıf öğretmenlerinin öğretim uygulamalarının daha önce incelenmemiş ve belirlenmemiş olması nedeniyle ilgili alan yazındaki boşluğa önemli katkı sağlayacağı düşünülmektedir. Ayrıca araştırma sonucunda sınıf öğretmenleri ve ilkokul dönemi çocuklar için öğretim materyalleri hazırlayan uzmanların da sözel problem türlerinin hepsine karşı bir farkındalık oluşturulması hedeflenmiştir.

$\mathrm{Bu}$ bağlamda çalışmamızın amacı, sınıf öğretmenlerinin öğrencilere sundukları sözel problem türlerini belirlemektir. Bu amaçla aşağıdaki sorulara yanıt aranmıştır:

1. Sınıf öğretmenlerinin toplama, çıkarma, çarpma ve bölme işlemlerine yönelik öğrencilere sundukları sözel problem türleri nelerdir?

2. Sınıf öğretmenlerinin toplama, çıkarma, çarpma ve bölmeye ilişkin sözel problem türlerine yönelik görüşleri nelerdir?

\section{Yöntem}

$\mathrm{Bu}$ çalışmada, karma yöntem araştırmaları modellerinden yakınsayan paralel desen kullanılmıştır. Yakınsayan paralel desen araştırmacının nitel ve nicel aşamaları, araştırma sürecinin aynı olan bir aşamasında eş zamanlı olarak uygulamasıyla oluşur (Cresswell ve Clark, 2015). Yakınsayan desenin amacı, araştırma problemini en iyi şekilde anlamak için aynı konu üzerinde farklı fakat birbirini tamamlayıc1 veri toplamaktır (Morse, 1991). Bu desenin kullanılmasındaki amaç, nicel yöntemlerle nitel yöntemlerin farklılaşan güçleri ve örtüşmeyen zayıflıklarını bir araya getirmektir (Patton, 1990). Bu desenin kullanılmasındaki bir diğer amaç ise nicel sonuçlarla nitel bulguları açıklamak, bir olgunun tam olarak anlaşılmasını geliştirmek için nicel ve nitel sonuçları birbirini tamamlayıcı şekilde sentezlemek ve bir sistemdeki çok sayıda seviyeyi karşılaştırmaktır. Bu doğrultuda araştırma sürecinde eş zamanlı olarak hem nicel (Sözel Problem Türleri Anket Formu) hem de nitel (Görüş Alma Formu) veri toplama araçları kullanılarak araştırmanın sorularına cevap aranmıştır.

\section{Örneklem/Çalışma Grubu}

Araştırmanın çalışma grubunu, Türkiye'nin güneyindeki bir ilin farklı okullarında görev yapan 104 sınıf öğretmeni oluşturmaktadır. Araştırmanın katılımcıları kolay ulaşılabilir örnekleme yöntemi ile belirlenmiştir. Araştırmanın örnekleme yöntemi, araştırmaya hız ve pratiklik sağladığı için tercih edilmiştir. Öğretmenlerin meslek yılları "0-5, 6-10, 11-15, 16 ve üstü yıl olarak dağılım göstermektedir.

\section{Veri Toplama Araçları}

Araştırmanın nicel verileri "Sözel Problem Türleri Anket Formu” kullanılarak toplanmıştır. Sınıf öğretmenlerinin matematik etkinliklerinde toplama, çıkarma, çarpma ve bölmeye ilişkin çocuklara sundukları sözel problemleri belirlemek amacıyla araştırmacılar tarafindan oluşturulan bir anket formu oluşturulmuştur. Formda, toplama ve çıkarmaya ilişkin 11; çarpma ve bölmeye ilişkin 9 adet sözel problem türünden oluşan problemler yer almaktadır. Formda öğretmenlerden toplama, çıkarma, çarpma ve bölme işlemlerini öğretirken hangi sözel problem 
türlerine yer veriyorsa o problem türünü işaretlemeleri istenmiştir. Ek 1'de bu formda yer alan problemlerden bazıları bulunmaktadır. Sözel problem türleri anket formu, ilgili alan yazın esas alınarak araştırmacılar tarafından oluşturulmuştur. Formun geçerliliğini ve güvenirliliğini sağlamak ve sınıf öğretmenlerinin toplama, çıkarma, çarpma ve bölme işlemlerine yönelik ögrencilere sundukları sözel problem türlerini belirleyebilmek için oluşturulan formun, belirlenen amaçlara uygun ve anlaşılır nitelikte olup olmadığını değerlendirmesi için öncelikle matematik eğitimi alanında bir uzman, bir matematik öğretmeni ve bir sınıf öğretmeninden görüşler alınmıştır. Uzman görüşleri doğrultusunda sorular tekrar gözden geçirilerek bazı düzenlemeler yapılmıştır. Daha sonra form 16 sınıf öğretmenine uygulanarak pilot çalışması gerçekleştirilmiştir. Bu pilot çalışma ile uygulama sürecinde ortaya çıkabilecek aksaklıklar giderilmeye çalışılmıştır. Bunun sonucunda gerekli düzenlemeler yapılarak forma son şekli verilmiştir.

Araştırmanın nitel verileri ise "Görüş Alma Formu" kullanılarak elde edilmiştir. Öğretmenlerin; toplama, çıkarma, çarpma ve bölme işlemlerini öğretirken problem türlerine nasıl karar verdikleri, belirttikleri problem türlerine neden yer verdikleri ve öğrencilere sunmadıkları problem türlerine neden yer vermediklerine ilişkin görüşleri sorulmuştur. Ek 2'de bu formda yer alan sorulardan bazıları bulunmaktadır. Sınıf öğretmenlerinin toplama, çıkarma, çarpma ve bölmeye ilişkin sözel problem türlerine yönelik görüşlerini belirleyebilmek için oluşturulan görüşme sorularının, belirlenen amaçlara uygun ve anlaşılır nitelikte olup olmadığını değerlendirmesi için matematik eğitimi alanında bir uzman, bir matematik öğretmeni ve bir sınıf öğretmeninden görüşler alınmıştır. Uzman görüşleri doğrultusunda sorular tekrar gözden geçirilerek bazı düzenlemeler yapılmıştır. Ardından araştırmanın katılımcıları arasında yer almayan 3 sınıf öğretmeni ile pilot çalışma yapılmıştır. Böylece bazı soru ifadeleri ve alt sorular düzenlenerek sorulara son şekli verilmiştir.

\section{İşlem}

Verilerin toplanması aşamasında araştırmacılar, Türkiye'nin güneyindeki bir ilde bulunan il milli eğitim müdürlüğüne bağl1 ilkokullarda görev yapan okul müdürleri ve öğretmenlerle görüşerek araştırmanın amacını anlatmışlardır. Daha sonra araştırmaya katılmayı kabul eden öğretmenlere, Sözel Problem Türleri Anket Formu ve Görüş Alma Formu bireysel olarak uygulanmıştır. Öğretmenlerin formu tamamlama süreleri yaklaşı olarak 30 dakika sürmüştür.

\section{Verilerin Analizi}

Çalışmada öğretmenlerden elde edilen verilerin analizindeki istatistiki işlemler için SPSS 22.0 İstatistik Paket Programı kullanılmıştır. Nicel verilerin çözümlenmesinde frekans ve yüzde dağılımları kullanılmıştır.

Görüşmelerden elde edilen verilere ise içerik analizi yapılmıştır. İçerik analizinde toplanan verilerden, ilk önce kavramsal yönleriyle kodlar daha sonra temalar oluşturulmuştur. $\mathrm{Bu}$ amaçla öğretmenlerin verdikleri cevaplar, tek tek okunarak araştırmanın amaçları çerçevesinde ortaya çıkan anlama göre belirli temalar oluşturulmuştur. Elde edilen veriler tablolar halinde düzenlenerek betimlenmiş, öğretmenlerin açıklamalarından doğrudan alıntılara tırnak içinde yer verilmiştir. Araştırmaya katılan öğretmenlerin görüşlerinin aktarılmasında öğretmenlere 1'den 104' e kadar sayılar verilmiş ve sayıların yanlarına cinsiyetlerini gösteren harfler yazılmıştır [1E (Görüşünden alıntı yapılan birinci öğretmenin erkek olduğunu; 5K (Görüşünden alıntı yapılan beşinci öğretmenin kadın olduğunu göstermektedir].

\section{Bulgular}

$\mathrm{Bu}$ bölümde öğretmenlerin; çocuklara sundukları sözel problem türlerine ve sözel problem türleriyle ilgili olarak öğretmenlerin görüşlerine ilişkin bulgulara yer verilmiştir. 


\section{Öğretmenlerin Çocuklara Sundukları Sözel Problem Türlerine İlişkin Bulgular}

Bu bölümde, öncelikle öğretmenlerin çocuklara sundukları toplama ve çıkarmaya ilişkin sözel problem türlerine (Tablo 4) ardından çarpma ve bölmeye ilişkin sözel problem türlerine (Tablo 5) ilişkin bulgulara yer verilmiştir.

Tablo 4.

Öğretmenlerin kullandıkları sözel problem türlerinin dağılımı

\begin{tabular}{|c|c|c|c|c|}
\hline Problem Türü & Problem Türü & $\begin{array}{c}\text { Örnek } \\
\text { Problemler }\end{array}$ & $\mathrm{f}$ & $\%$ \\
\hline \multirow[t]{3}{*}{ Birleştirme } & $\begin{array}{l}\text { Sonuç miktarın bilinmediği } \\
\text { durumlar }\end{array}$ & $6+4=?$ & 97 & 90,7 \\
\hline & $\begin{array}{l}\text { Değişim miktarının bilinmediği } \\
\text { durumlar }\end{array}$ & $5+?=12$ & 86 & 80,4 \\
\hline & $\begin{array}{l}\text { Başlangıç miktarın bilinmediği } \\
\text { durumlar }\end{array}$ & $?+7=9$ & 78 & 72,9 \\
\hline \multirow[t]{3}{*}{ Ayırma } & $\begin{array}{l}\text { Sonuç miktarın bilinmediği } \\
\text { durumlar }\end{array}$ & $8-4=?$ & 97 & 90,7 \\
\hline & $\begin{array}{l}\text { Değişim miktarının bilinmediği } \\
\text { durumlar }\end{array}$ & $15-?=6$ & 82 & 76,6 \\
\hline & $\begin{array}{l}\text { Başlangıç miktarın bilinmediği } \\
\text { durumlar }\end{array}$ & $?-7=5$ & 72 & 67,3 \\
\hline \multirow{3}{*}{$\begin{array}{l}\text { Parça-Parça- } \\
\text { Bütün } \\
\text { Karş1laştırma }\end{array}$} & Parçanın bilinmediği durumlar & $3+?=8$ & 93 & 86,9 \\
\hline & Bütünün bilinmediği durumlar & $3+5=?$ & 87 & 81,3 \\
\hline & Farkın bilinmediği durumlar & $6-2=?$ & 93 & 86,9 \\
\hline \multirow{2}{*}{$\cos 20$} & $\begin{array}{l}\text { Büyük çokluğun bilinmediği } \\
\text { durumlar }\end{array}$ & $5+4=?$ & 80 & 74.8 \\
\hline & $\begin{array}{l}\text { Küçük çokluğun bilinmediği } \\
\text { durumlar }\end{array}$ & $6-3=?$ & 69 & 64,5 \\
\hline
\end{tabular}

Tablo 4 incelendiğinde, öğretmenler tarafından çocuklara birleştirme türü sözel problemlerden; sonuç miktarın bilinmediği durumlar $(\% 90,7)$, değişim miktarının bilinmediği durumlar $(\% 80,4)$ ve başlangıç miktarın bilinmediği durumlar $(\% 72,9)$ problem türünde sözel problemler sundukları belirlenmiştir. Bu analiz doğrultusunda toplama işlemine ilişkin problem türlerinde, öğretmenler tarafindan çocuklara en fazla sunulan sözel problem türünün sonuç miktarının bilinmediği durumlar türünde olduğu görülmektedir. Öğretmenler ayırma türü sözel problemlerde ise sonuç miktarının bilinmediği durumlar $(\% 90,7)$ problem türünde daha çok problem sundukları görülürken; değişim miktarının bilinmediği durumlar $(\% 76,6)$ ve başlangıç miktarının bilinmediği durumlar $(\% 67,3)$ problem türlerinde ise nispeten daha az problem sundukları belirlenmiştir. Bununla birlikte parça-parça-bütün problemlerinde öğretmenler, parçanın bilinmediği durumlar $(\% 86,9)$ ve bütünün bilinmediği durumlar $(\% 81,3)$ türünde problemler sundukları görülmektedir. Karşılaştırma türü problemler de ise öğretmenler, farkın bilinmediği durumlar $(\% 86,9)$ ve büyük çokluğun bilinmediği durumlar $(\% 74,8)$ problem türlerini daha çok sundukları görülürken; küçük çokluğun bilinmediği durumlar $(\% 64,5)$ problem türünde nispeten daha az problem sundukları görülmektedir. 
Sınıf öğretmenlerinin matematik etkinliklerinde çocuklara sundukları çarpma ve bölmeye ilişkin sözel problem türleri ise Tablo 5'de sunulmuştur.

Tablo 5.

Öğretmenlerin kullandıkları sözel problem türlerinin dağılımı

\begin{tabular}{|c|c|c|c|}
\hline Problem Türü & Problem Türü & $\mathrm{f}$ & $\%$ \\
\hline $\begin{array}{l}\text { Eş-Grup } \\
\text { Problemleri } \\
\text { (Çarpma) }\end{array}$ & $\begin{array}{lcc}\begin{array}{l}\text { Bütünün } \\
\text { (Tekrarlı Toplama) }\end{array} & \text { Bilinmediği } & \text { Durumlar } \\
\begin{array}{l}\text { Bütünün } \\
\text { (Oran) }\end{array} & \text { Bilinmediği } & \text { Durumlar } \\
\end{array}$ & $\begin{array}{l}87 \\
86\end{array}$ & 81,3 \\
\hline $\begin{array}{l}\text { Eş-Grup } \\
\text { Problemleri } \\
\text { (Parçalamalı } \\
\text { Bölme) }\end{array}$ & $\begin{array}{l}\text { Grup Büyüklüğünün Bilinmediği } \\
\text { Durumlar (Adil Paylaşım) } \\
\text { Grup Büyüklügünün Bilinmediği } \\
\text { Durumlar (Oran) }\end{array}$ & 92 & 86,0 \\
\hline $\begin{array}{l}\text { Eş-Grup } \\
\text { Problemleri } \\
\text { (Ölçüm } \\
\text { Bölmesi) }\end{array}$ & $\begin{array}{llc}\text { Grup } & \text { Sayısının } & \text { Bilinmediği } \\
\text { Durumlar } & \text { (Tekrarlı Çıkarma) } \\
\text { Grup } & \text { Sayısının } & \text { Bilinmediği } \\
\text { Durumlar (Oran) } & \end{array}$ & 87 & 81,3 \\
\hline $\begin{array}{l}\text { Karşılaştırma } \\
\text { Problemleri }\end{array}$ & $\begin{array}{l}\text { Çarpma } \\
\text { Parçalamalı Bölme } \\
\text { Ölçüm Bölmesi }\end{array}$ & $\begin{array}{l}89 \\
77 \\
74\end{array}$ & $\begin{array}{l}83,2 \\
72,0 \\
69,2\end{array}$ \\
\hline
\end{tabular}

Tablo 5 incelendiğinde öğretmenler tarafindan çocuklara, çarpma problemlerinden (eşgrup problemleri); tekrarlı toplama $(\% 81,3)$ ve oran $(\% 80,4)$ türünde problemleri çoğunlukla sundukları görülmektedir. Parçalamalı bölme (eş-grup problemleri) türü problemlerde ise adil paylaşım $(\% 86)$ türünün daha çok sunulduğu görülürken; oran $(\% 72,9)$ türü problemlerin nispeten daha az sunulduğu belirlenmiştir. Bununla birlikte ölçüm bölmesi (eş-grup problemleri) problemlerinde öğretmenlerin, tekrarlı çıkarma (\%81,3) türünde daha çok problem sundukları görülürken; oran $(\% 52,3)$ problem türünde daha az problem sundukları görülmektedir. Karşılaştırma problemlerinde ise öğretmenler, çarpma $(\% 83,2)$ ve parçalamalı bölme $(\% 72)$ problem türlerinde daha çok problem sundukları görülürken; ölçüm bölmesi $(\% 69,2)$ problem türünde nispeten daha az problem sundukları belirlenmiştir.

\section{Görüşsme Bulguları}

Öğretmenlerin; öğrencilere toplama, çıkarma, çarpma ve bölme işlemlerini öğretirken problem türlerine nasıl karar verdikleri, belirttikleri problem türlerine neden yer verdikleri ve öğrencilere sunmadıkları problem türlerine neden yer vermediklerine ilişkin görüşleri sorulmuştur. Öğretmenlerin, problem türlerine nasıl karar verdikleri ve belirttikleri problem türlerine neden yer verdiklerine ilişkin görüşleri benzer olduğu için öğretmenlerin bu konudaki görüşleri ortak temalar altında sunulmuştur. 
Tablo 6.

Öğretmenlerin sözel problem türlerine yönelik görüşleri

\begin{tabular}{llc}
\hline Tema & f & $\%$ \\
\hline Gelişim Özelliği & 71 & 68,26 \\
Öğretim Programı & 23 & 22,11 \\
Günlük hayat ilişkisi & 21 & 20,19 \\
Basitten Karmaşığa İlkesi & 19 & 18,26 \\
Çeşitlilik & 14 & 13,46 \\
Düşünme Becerisi & 12 & 11,53 \\
Anlaşılabilirlik & 10 & 9,61 \\
Altyapı & 9 & 8,65 \\
Kaynak Kitap & 5 & 4,80 \\
Pekiştirme & 3 & 2,88 \\
\hline
\end{tabular}

Yapılan analizler sonucunda sınıf öğretmenleri; öğrencilere toplama, çıkarma, çarpma ve bölme işlemlerini ögretirken problem türlerine nasıl karar verdikleri ve belirttikleri problem türlerine neden yer verdiklerine ilişkin birbirinden farklı görüşler sunmuşlardır. Öğretmenlerden beşinin belirttiği görüşler sorulan soru ile ilişkilendirilemediği için herhangi bir tema altına yerleştirilememiştir. Öğretmenlerden on altısı ise bu konu ile ilgili herhangi bir görüş belirtmemiştir. Geliştirilen bu temalar öğretmen adaylarının açıkladıkları gerekçelerdeki ortak özelliklere göre "Gelişim Özelliği”, "Öğretim Programı", "Günlük hayat ilişkisi”, "Basitten Karmaşı̆̆a İlkesi”, "Gereksinim”, "Düşünme Becerisi”, “Anlaşılabilirlik”, “Altyapı”, “Kaynak Kitap", ve "Pekiştirme" olmak üzere 10 tema altında toplanmıştır. Aşağıda, sınıf öğretmenlerinin görüşleri, araştırma sonucunda ortaya çıkan temalar altında, gerekçeleriyle birlikte açıklanmıştır.

Tema 1. Gelişim Özelliği: Öğretmenler (71) çocuklara sözel problem sunarken; öğrencilerin bilişsel gelişim düzeyleri, sınıf seviyesi, öğrencinin hazırbulunuşluk durumu, öğrencinin ilgi, ihtiyaç ve isteklerine göre problem türlerine karar verdiklerini belirtmişlerdir. Bir erkek öğretmen bu konu ile ilgili görüşünü “ Ögrencilerin bulunduğu sinıfa ve sinıftaki seviyelere göre problem türü seçerek başllyorum. Konu ilerleyip, ögrenciler özümsedikçe farklı problem türlerine yer veriyorum" (22E) şeklinde ifade etmiştir. Aşağıda diğer öğretmenlerin açıklamalarına örnekler verilmiştir.

"Özellikle hazırbulunuşluk düzeylerine bakıyorum. 4. sinıf kazanımını anlamıyor ve bilmiyorlarsa 3. sinıfin bir alt kazanımından başlayarak yapıyorum." (75K)

"Genellikle farklı soru türlerine yer vermeye çallşlyorum. Bunlart yaparken, sinıf seviyesini düs̈̈nerek bazı problem türlerine yer vermiyorum."(30E)

"Öğrenci ilgi, ihtiyaç ve isteklerine, ögrenci farklllıklarına göre karar veriyorum” (94K)

Tema 2. Öğretim Programı: Öğretmenler (23), öğrencilere dört işlemi öğretirken müfredatta yer alan kazanımlara göre sözel problem türlerine karar verdiklerini ifade etmişlerdir. Bir erkek öğretmen bu konuya yönelik görüşünü "Öğrencilere toplama, çıkarma, çarpma ve bölme işlemlerini ögrretirken, yıllık ve günlük planımdaki kazanımlara bakarak karar veriyorum." (39E) şeklinde ifade etmiştir. Aşağıda diğer öğretmenlerin açıklamalarına örnekler verilmiştir.

"Kazanımlarda yapılması gereken çalışmaya uygun problem türüne yer veriyorum.” (16E) "Ë̆itim öğretim müfredatına uygun şekilde kazanımları ögretmeye yönelik basitten zora doğru seçim yapıyorum” (98E) 
Canbazoğlu ve Tarım

Tema 3. Günlük hayat ilişkisi: Bu tema altında görüş bildiren öğretmenler (21), öğrencilerin kendi günlük yaşamlarında matematiği kullanabilecekleri ve faydalanabilecekleri durumlara göre sözel problem türlerine karar verdiklerini belirtmişlerdir. Bir kadın öğretmen bu konu ile ilgili düşüncesini "Öğrettiğimiz işlemlerin günlük hayatta kullanım durumuna göre karar veriyoruz." (19K) şeklinde görüş bildirmiştir. Aşağıda diğer öğretmenlerin görüşlerine yer verilmiştir.

"Yaşantılarına dair kavranması daha kolay olan problemleri tercih ediyorum." (90E)

"Gerçek hayatlarında karşılaşabilecekleri durumları kullanarak problem oluşturuyorum." (26E)

Tema 4. Basitten Karmaşığa İlkesi: Öğretmenler (19), öğrencilerin ilk olarak problemi anlayabilmeleri için kolay sorulardan başlayıp ardından daha kapsamlı ve karmaşık problemlere bir başka deyişle aşamalılık ilkesine göre problemlere karar verdiklerini belirtmişlerdir. Bir kadın öğretmen bu konu ile ilgili görüşünü "Konuyla ilgili olarak seviyelerine uygun olacak şekilde basitten zora doğru çok çeşitli problemlerin çözümüne yer vermeye çalışıyorum." (93K) şeklinde ifade etmiştir. Aşağıda diğer öğretmenlerin açıklamalarına yer verilmiştir.

"Zorluk derecesine göre basitten zora doğru bir yol izliyorum. Önce öğretilen dört işlemin kavratılmast sonra bilinmeyeni bulma problemlerine yer veriyorum." (38E)

"Problem türlerinde aşama aşama ilerliyorum. Basitten zora doğru, bilinmeyenlerin yerlerini değiştirerek problemleri uyguluyorum." (65K)

Tema 5. Çeşitlilik: Öğrencinin her problem türünü görmesi ve problem türleri hakkında gerekli bilgi ve beceriye sahip olması gerektiğinden dolayı öğretmenler (14) belirttikleri problem türlerini sunduklarını söylemişlerdir. Bir kadın öğretmen bu konu ile ilgili düşüncesini "Öğrencilerimin her türlü soru tarzını ögrenmesini amaçlyyorum. Tek yönlülükten uzak olmalarına çalışıyorum." (67K) ş̧eklinde ifade etmiştir. Aşağıda diğer öğretmenlerin açıklamalarına yer verilmiştir.

"Değişik problem tiplerine alışkanlık olması için olabildiğince çeşitli problem çözüyoruz." (104E)

“Tüm problem türleri hakkında bilgi sahibi olsunlar istiyorum.” (86K)

Tema 6. Düşünme Becerisi: Öğretmenler (12), öğrencilerin farklı bakış açıları kazanmaları ve düşünme becerilerini geliştirecek durumlara göre, problem türlerine karar verdiklerini belirtmişlerdir. Bir erkek öğretmen bu konu ile ilgili düşüncesini "Öğrencileri çok yönlü düşündürmeye yöneltmek için yer veriyorum." (76E) şeklinde görüş belirtirken; bir başka öğretmen ise "Her yönlü düşünebilmeleri için ... çeşitli türlerde çözmeye, ögrretmeye gayret ediyorum." (95K) görüşünü belirtmiştir.

Tema 7. Anlaşılabilirlik: Öğretmenler (10) işaretledikleri problem türlerinin, öğrenciler tarafindan anlaşılması daha kolay olduğundan dolayı bu problem türlerine yer verdiklerini söylemiş̧lerdir. Aşağıda öğretmenlerin açıklamalarına yer verilmiştir.

"Matematik ilkokul seviyesinde oldukça soyut bir derstir. Matematiği sevdirmek okul öncesi ve sinıf ögretmenlerinin elindedir. Matematiği bir zorunluluk gibi vermek yerine hayatın bir parçası olarak vermek, olabildiğince somutlaştırmak öğrenciye matematiği sevdirir. Bu yüzden üst düzey kafa karıştırıcı problemler yerine ögrencinin anlayabileceği somut problemlere yer vermekteyim." (34E)

“Anlaşılırlıkları oldukça kolay oldu için tercih ederim.” (90E) 
Tema 8. Altyapı: Öğrencilerin; dört işlemin mantığını, özünü ve amacını daha iyi anlayabilmeleri için öğretmenler (9) belirtikleri problemlere yer verdiklerini ifade etmişlerdir. Aşağıda öğretmenlerin açıklamalarına yer verilmiştir.

\section{"Dört işlemin amacını, kullanımını daha iyi kavratmak için problem türlerini kullanıyorum." (48E) \\ "Çocuğun verilen, istenen ve çözüm seçeneklerini en detayl bir şekilde öğrenmesi açısından işaretlediğim problem türlerine yer veriyorum." (57E) \\ "İşlemlerin mantığını daha kolay anladı̆̆ için yer veriyorum." (52K)}

Tema 9. Kaynak Kitap: Öğretmenler (5) ders ve matematik etkinlik kitaplarında yer alan problem türlerine göre, belirttikleri problem türlerine yer verdiklerini belirtmişlerdir. Bir erkek öğretmen bu konudaki fikrini "Ders kitabindaki örneklere uygun problem çözüyoruz." (18E) şeklinde ifade etmiştir. Bir başka öğretmen ise "Ders kitaplarından ve kaynak kitaplardan bakarak karar veriyorum." (66K) görüşünde bulunmuştur.

Tema 10. Pekiştirme: Öğretmenler (3), öğrencinin problem çözme konusunda beceri kazanmas1 ve öğrendiklerini pekiştirmesi amacıyla çeşitli problem türlerine yer verdiklerini ifade etmiş̧lerdir. Bir kadın öğretmen bu konu ile ilgili "Farkl yollardan soru çözümlerinde konunun daha iyi pekiştirildiği için işaretlediğim problem türlerine yer veriyorum." (72K) şeklinde görüş belirtmiştir. Bir başka öğretmen ise "Dört işlemi pekiştirmek... amacıyla veriyorum." (11E) ifadesinde bulunmuştur.

Öğretmenlere neden bazı problem türlerine yer vermedikleri sorulduğunda ise çoğunlukla çocukların gelişim özelliklerine uygun olmadığı, öğretim programında yer alan kazanımları kapsamadığı ve öğrenciler tarafindan anlaşılmasının zor olduğu bundan dolayı başarısızlık duygusu yaşatmak istemediklerini belirtmişlerdir.

\section{Tartışma ve Sonuç}

$\mathrm{Bu}$ araştırma sonucunda elde edilen bulgular, sınıf öğretmenlerinin öğrencilere sundukları sözel problem türlerine ilişkin bazı ipuçları sunmaktadır. Yapılan araştırmalar, öğretmenlerin çocuklara sözel problem türlerinin hepsini benzer oranlarda sunmadıklarını göstermesine rağmen (Nures ve Brgant, 2008; Peterson, Fennema ve Carpenter, 1989; Sperry Smith, 2001; Van de Walle, Karp ve Bay-Williams, 2016) araştırmada öğretmenler matematik etkinliklerinde çocuklara toplama, çıarma, çarpma ve bölmeye ilişkin problemler sunarken problem türlerinin hepsine çoğunlukla yer verdiklerini ifade etmişlerdir. Bu sonuç ise bu konuda öğrencilerle yapılmış araştırmaların (Haylock ve Cockburn, 2004; Nures ve Brgant, 2008; Tarım, 2017) sonuçları ile tezatlık göstermektedir. Araştırmalarda öğrencilerin "başlangıç miktarının bilinmediği durumlar" ve "karşılaştırma problemleri" türlerinde başarı düzeylerinin düşük olduğu bununla birlikte öğrencilerin sözel problemleri çözme yeteneklerinin problemlerdeki bilinmeyen türüne göre değişiklik gösterdiği belirlenmiştir. Öğrencilerin problem çözme becerileri üzerinde etkili olan bir diğer önemli etken ise ders ve etkinlik kitaplarıdır. Türkiye'de ilköğretim kitaplarında yer alan sözel problem türlerini inceleyen araştırmalar (Olkun ve Toluk, 2002; Tarım, 2017) ders ve çalışma kitaplarında problem türlerinin hepsine yer verilmediğini ortaya koymuşlardır. Bu durumda öğrenci başarısının düşük ve ders ile etkinlik kitapları bu türlerle ilgili eksik olmasına rağmen öğretmenlerin bu konudaki iddiaları arasında bir çelişki olduğu söylenebilir.

Genel olarak değerlendirdiğimizde ise sınıf öğretmenleri tarafindan toplama ve çıkarmaya ilişkin en fazla sunulan problem türlerinin; birleştirme ve ayırma problemlerinden sonuç miktarının bilinmediği durumlar; parça-parça-bütün problemlerinden parçanın bilinmediği durumlar; karşılaştırma problemlerinden ise farkın bilinmediği durumlara yönelik problem türleri olduğu belirlenmiştir. Bir başka deyişle öğretmenlerin sonuç bilinmeyenli problemlere daha çok odaklandıkları söylenebilir. Benzer şekilde Sarıbaş ve Aktaş Arnas (2016) 
tarafindan yapılan çalışmada, okul öncesi öğretmenlerinin çocuklara çoğunlukla sonuç bilinmeyenli problem türünde problemler sundukları belirlenmiştir. Oysaki bu konudaki araştırmalar (Nures ve Brgant, 2008; Sperry Smith, 2001; Van de Walle, Karp ve Bay-Williams, 2016) çocukların sözel problemleri anlama ve çözme süreçlerinde başarılı olabilmeleri için sözel problem türlerinin hepsinin yeterli sayıda çocuklara sunulması gerektiğini ifade etmektedir.

Sınıf öğretmenlerinin matematik etkinliklerinde çocuklara sundukları çarpma ve bölmeye ilişkin en fazla sunulan problem türlerinin; eş-grup problemlerinden tekrarlı toplama, adil paylaşım, ölçüm bölmesi ve tekrarlı çıkarma ile karşılaştırma problemlerinden çarpma türü problemler olduğu belirlenmiştir. En az tercih edilen sözel problem türlerinin ise ölçüm bölmesi problemlerinden oran ve karşlaştırma problemlerinden ölçüm bölmesi problem türlerinin olduğu saptanmıştır. Genel olarak değerlendirdiğimizde ise, öğretmenler matematik etkinliklerinde çocuklara çarpma ve bölmeye ilişkin problemler sunarken problem türlerinin hepsine eşit oranda yer vermemektedir. Çarpımsal işlemlerle çalışmadaki kavramsal engellerden biri, grup öğelerini tek bir varlık olarak anlamaktır. (Blote, Lieffering ve Ouewhand, 2006; Clark ve Kamii, 1996; Van de Walle, Karp ve Bay-Williams, 2016). Örneğin çocuklara "Her birinde 6 kalem olan 5 kutuda (toplam) kaç kalem vardır?" sorusunu sorduğumuzda, çocuklar beş kutuda bulunan toplam kalem sayısını sayarak bu işlemi yapacaklardır. Bu problemle ilgili olarak çocukların "beş tane altılı küme" gibi düşünmesi için her bir altılı kümeyi sayılacak tek bir nesne olarak kavramsallaştırmasını gerektirmektedir. Bununla birlikte öğrenciler çarpmaya ilişkin kavramları öğrenmeden önce basit çarpma içeren sözel problemler çözdüğünde, çoğunlukla problemlerin çözümünü tekrarlı toplama denklemi biçiminde yazacaklardır (Van de Walle, Karp ve Bay-Williams, 2016). Bu durum öğretmen için çarpma işaretini ve çarpmada yer alan iki bileşenin ne anlama geldiğini anlatmak için bir kolaylık oluşturabilir. Bu bağlamda değerlendirdiğimizde, öğretmenlerin çarpma ve bölme işleminde yer verdiği sözel problem türlerinin çoğunlukla tekrarlı çıkarma ve tekrarlı toplama türlerine yönelik olmasında, öğrencilerin bahsedilen tekil yapıyı anlamlandıramayacaklarını düşünmeleri ve öğrencilerin çarpma işlemini öğrenmeden önce zihinlerinde oluşan tekrarlı toplama yapısından dolayı olabileceği düşünülmektedir. Ancak, birinci sınıf çocuklarının çarpma ve bölme problemlerini hatta kalan içeren bölmeyi çözmede oldukça başarılı olduklarını ifade eden araştırmalar bulunmaktadır (Carpenter, Ansell, Franke, Fennema ve Weisbeck, 1993; Carpenter, Fennema, Franke, Levi ve Empson, 2014). Mulligan ve Mitchelmore (1997), öğrencilerin ilkokuldan itibaren mümkün olduğunca sözel problem türleriyle çeşitli deneyimler yaşamaları gerektiğini ve çarpma ve bölme işlemlerinin öğretim programlarında birbiriyle daha çok ilişkili olması gerektiğini vurgulamıştır.

Sınıf öğretmenleri; öğrencilere toplama, çıkarma, çarpma ve bölme işlemlerini ögretirken problem türlerine nasıl karar verdikleri, belirttikleri problem türlerine neden yer verdikleri ve öğrencilere sunmadıkları problem türlerine neden yer vermediklerine ilişkin düşüncelerini çeşitli görüşlerle ifade etmişlerdir. Öğretmenlerin büyük çoğunluğu çocukların gelişim özelliklerini göz önünde bulundurarak çocuklara sözel problem türlerini sunduklarını belirtmişlerdir. Bazı problem türlerine yer vermeme nedenlerini ise çoğunlukla, çocukların gelişim özelliklerine ve yaşlarına uygun olmaması ile müfredatta belirtilen kazanımlarda yer almaması gerekçelerini kullanmışlardır. Ancak öğretmenlerdeki "bazı problem türlerinin, çocukların gelişimine uygun olmadiğı" düşüncesi çocukların işlemsel matematiği öğrenmeden önce bile sayılarla ilgili çoğu problemi çözebileceğini ifade eden çalışmalarla (Carpenter, Carey ve Kouba, 1990; Sarama ve Clements, 2009) zıtlık göstermektedir. Sarıbaş ve Aktaş Arnas (2017) tarafından yapılan çalışmada da benzer sonuçlara ulaşılmıştır. Öğretmenler, matematik etkinliklerinde bazı problem türlerini çocuklara sunmama nedenlerini, problem türlerinin onların gelişim özelliklerine ve yaşlarına uygun olmaması olarak açıklamışlardır. Öğretmenlerin sundukları problem türleri ile ilgili bu sonuçlar, onların sözel problem kurma ve çözme yeterlilikleri ile ilişkili olduğunu düşündürmektedir. Örneğin Albayrak, İpek ve Işık (2006) tarafindan yapılan çalışmada, temel matematiksel işlem becerilerinin kazandırılması sürecinde öğretmenlerin problem kurma-çözme çalışmalarına yer verme düzeyleri ile hizmet öncesi 
dönemde öğretmen adaylarının bu konudaki becerileri arasında bir ilişki olup olmadı̆̆ını belirlemeyi amaçlamışlardır. Elde edilen bulgulara göre, öğretmenlerin sınıf içi uygulamalarda problem kurma-çözme sürecinde yetersiz kaldıkları belirlenmiştir. Aynı zamanda hizmet öncesi dönemde sınıf öğretmeni adaylarının, problem çözme ve kurma becerilerinde zorluk yaşadıkları tespit edilmiştir. $\mathrm{Bu}$ bağlamda değerlendirdiğimizde, bu çalışmada hizmet içinde yer alan öğretmenlerin bazı sözel problem türlerine ilişkin çekingen yaklaşımlarının sebebi olarak sözel problemler konusunda yeterli bilgi ve becerilerinin olmadığı yönünde yorumlanabilir.

\section{Öneriler}

- Öğretmenlerin büyük çoğunluğu çocukların gelişim özelliklerini göz önünde bulundurarak problem türlerine yer verdiklerini belirtmişlerdir. Bazı problem türlerine yer vermeme nedenlerini ise çoğunlukla, çocukların gelişim özelliklerine ve yaşlarına uygun olmaması ile müfredatta belirtilen kazanımlarda yer almaması gerekçelerini kullanmışlardır.

- Elde edilen sonuçlar doğrultusunda, çocukların problem çözmede başarılı olabilmeleri için, çeşitli sözel problem türleriyle etkileşim içerisinde yer alması gerekmektedir. Bunun için öğretmenlerin matematik etkinliklerinde hangi problem türlerine yer verdikleri, hangilerine yer vermediklerini ya da hangi oranlarda yer verdiklerini belirlemek için ders içi gözlemler yapılmalıdır.

- Benzer bir çalışma sınıf öğretmeni adaylarıyla da yapılabilir. Sınıf öğretmeni adaylarının sözel problem türlerine yönelik farkındalıkları belirlenebilir. Bu bağlamda lisans eğitimi sürecinde matematik öğretimi derslerinde öğretmen adaylarının sözel problem türlerine yönelik beceri ve farkındalıklarını geliştirebilecek etkinlikler yapılabilir.

- Araştırma sürecinde ilkokul düzeyindeki matematik etkinlik ve ders kitaplarında sözel problem türlerinin hepsine yer verilmediği görülmüştür. Bu bağlamda ilkokul çocukları için eğitim materyalleri hazırlayan uzmanlar sözel problem türlerinin hepsine karşı bir farkındalık oluşturmalıdır.

\section{Kaynaklar}

Albayrak, M., İpek, A. S. ve Işık, C. (2006). Temel işlem becerilerinin öğretiminde problem kurma-çözme çalışmaları. Erzincan Ĕgitim Fakültesi Dergisi, 8(2), 1-11.

Blote, A., Lieffering, L. ve Ouwehand, K. (2006). The development of many-to-one counting in 4 year old children. Cognitive Development, 21(3), 332-348.

Carpenter, T. P., Ansell, E., Franke, M. L., Fennema, E. ve Weisbeck, L. (1993). Models of problem solving: a study of kindergarten children's problem-solving processes. Journal for Research in Mathematics Education, 24(5), 428-441.

Carpenter, T. P., Fennema, E., Franke, M. L., Levi, L. ve Empson, S. (2014). Children's mathematics: Cognitively guided instruction. Portsmouth, NH: Heinemann.

Carpenter, T.P., Carey, D.A. ve Kouba, V.L. (1990). A problem-solving spproach to the operations. In mathematics for the young child. Reston, VA: National Council of Teachers of Mathematics.

Clark, F. B. ve Kamii, C. (1996). Identification of multiplicative thinking in children in grades 1-5. Journal for Research in Mathematics Education, 27(1), 41-51.

Creswell, J. W. ve Clark, V. (2015). Karma Yöntem Araştırmaları Tasarımı ve Yürütülmesi. Ankara: Anı Yayıncilik.

Desli, D. ve Loukidou, H. (2014). Addition and subtraction word problems in greek grade a and grade b mathematics textbooks: distribution and children's understanding. International Journal for Mathematics Teaching and Learning, 8, 340.

Gonzalez Thompson, A. (1984). The relationship of teachers' conceptions of mathematics and mathematics teaching to instructional practice. Educational Studies in Mathematics, 15, $105-127$. 
Haylock, D. ve Cockburn, A. (2004). Understanding mathematics in the lower primary years. London: Paul Chapman Publishing.

Hill, H. C., Rowan, B. ve Ball, D. L. (2005). Effects of teachers' mathematical knowledge for teaching on student achievement. American Educational Research Journal, 42 (2), 371406.

Milli Eğitim Bakanlığı [MEB] (2017). Illkokul matematik dersi ögretim programı. Ankara: Talim Terbiye Başkanlığı Yayınları.

Morse, J. M. (1991). Approaches to qualitative quantitative methodological triangulation. Nursing Research, 40, 120-123.

Mulligan, J. T. ve Mitchelmore, M. C. (1997). Young children's intuitive models of multiplication and division. Journal for Research in Mathematics Education, 28(3), 309-330.

Nures, T. ve Brgant, P. (2008). Children doing mathematics (S. Koçak çev.). İstanbul: Doruk yayıncilik.

Olkun, S. ve Toluk, Z. (2002). Textbooks, word problems and student success on addition and subtraction. International Journal for Mathematics Teaching and Learning.

Parmjit, S. ve Teoh, S. H. (2010). An analysis of addition and subtraction word problems in mathematics textbooks used in Malaysian primary school classrooms. Brunei International Journal of Science and Mathematics Education, 2(1), 68-85.

Patton, M. Q. (1990). Qualitative evaluation and research methods. Newbury Park, CA: Sage.

Peterson, P. L., Fennema, E. ve Carpenter, T. (1989). Using knowledge of how students think about mathematics. Educational Leadership, 46(4), 42-46.

Sarama, J. ve Clements, H.D. (2009). Early childhood mathematics education research. New York and London: Routledge.

Sarıbaş, Ş. ve Aktaş Arnas, Y. (2016). Preschool children's verbal problem solving skills and the types of verbal problems that teachers present to children. Pegem Ĕgitim ve Ögretim Dergisi, 6(4), 549-568

Sarıbaş, Ş. ve Aktaş Arnas, Y. (2017). Okul Öncesi Dönemde Öğretmenler Ve Eğitim Materyalleri Çocuklara Hangi Tür Sözel Problemleri Sunuyor? Necatibey Faculty of Education Electronic Journal of Science and Mathematics Education, 11(1), 81-100.

Singh, P. (2006). An analysis of word problems in school mathematics texts: Operation of addition and subtraction. Journal of Science and Mathematics Education in Southeast Asia, 29(1), 41.

Sperry Smith, S. (2001). Early childhood mathematics. U.S.A.: Allyn and Bacon.

Swars, S., Hart, L. C., Smith, S. Z., Smith, M. E. ve Tolar, T. A. (2007). Longitudinal study of elementary pre-service teachers' mathematics beliefs and content knowledge. School Science and Mathematics, 107(9), 325-335.

Tarım, K. (2017). İlkokul öğrencilerinin matematiksel sözel problemleri çözme düzeyleri ve bu problemlerin ders kitaplarındaki dağılımı. Çukurova Üniversitesi Ĕ̈itim Fakültesi Dergisi, 46(2), 639-648.

Tarım, K. ve Deretarla Gül, E. (2003). Anasınıfı ve ilköğretim birinci sınıf öğrencilerinin toplama ve çıkarma becerilerinde kullandıkları stratejilerin incelenmesi. OMEP Dünya Konsey Toplantısı, Kuşadası, 1, 270-283.

Van de Walle, J. A., Karp, K. S. ve Bay-Williams, J. M. (2016). Elementary and middle school mathematics: Teaching developmentally. (Seventh edition) New York: Addison Wesley Longman.

Yaman, S. ve Dede, Y. (2005). Matematik ve fen eğitiminde problem kurma uygulamaları. Ondokuz Mayıs Üniversitesi Eğitim Fakültesi Dergisi, 20(1), 1-11. 


\section{Extended Abstract}

\section{Introduction}

Basic mathematical skills to be acquired for children in primary education are; addition, subtraction, multiplication, and division. In this period, it is important to present the situation, facts, and problems in the form of verbal problems in order to enable the children to solve and construct addition, subtraction, multiplication and division operations (Tarım \& Deretarla Gul, 2003).

Verbal problems for addition, subtraction, multiplication and division can be classified in different ways. Van De Walle, Karp and Bay-Williams (2016) classified the types of problems related to addition and subtraction as "joining, separating, part-part-whole, compare problems". The types of problems related to multiplication and division are equal groups problems: multiplication / partition division / measurement division; comparison problems: multiplication / partition division / measurement division. The ability of children to solve verbal problems may differ according to the types of problems and the unknown variation in the problems (Haylock \& Cockburn, 2004; Nures \& Brgant, 2008; Sarama \& Clements, 2009).

Teachers have an important role in having students have verbal problem solving and building skills and competencies. There are studies that show that teachers have the ability to effectively teach mathematics, and that mathematical knowledge is a significant influence on student achievement (Gonzalez Thompson, 1984; Hill, Rowan \& Ball, 2005; Swars, Hart, Smith, Smith \& Tolar 2007). In this context, it is thought that the teachers should be at the level of sufficient mathematical knowledge, skills and awareness in order for the students to be competent in mathematical knowledge and skills. Considering this, it is important that the knowledge, skills and awareness about the types of verbal problems of teachers are high and these skills are transferred to the classroom environment. Rather than having students with a high awareness level perform single-level verbal problem-solving exercises, they may contribute to the development of their superior cognitive skills and their use of problem-solving processes by involving many of the verbal problem types. When the results of the literature are evaluated, it is considered that classroom teachers will make a significant contribution to the vacancy in the related field because the presentation of verbal problem types to children has not been examined previously and has not been determined. The purpose of our work in this context is to identify the types of verbal problems that classroom teachers offer to students. For this purpose, the following questions were asked:

1. What are the types of verbal problems that primary school teachers offer to students for the addition, subtraction, multiplication and division problems?

2. What are the opinions of primary school teachers on the types of verbal problems related to addition, subtraction, multiplication and division?

\section{Method}

The study was conducted by using convergent parallel design, one of the mixed method research designs. The participants of the study consisted primary school teachers' working at public schools in the district of southern province in Turkey's. The quantitative data of the study were collected using a questionnaire. The qualitative data of the study was obtained by using the "Interview Form". SPSS 22.0 Statistical Package Program was used for the statistical analysis of the analysis of the data obtained from the teachers in the study. Descriptive statistics, in other words frequency and percentage distributions, are used in the analysis of quantitative data. Content analysis was conducted on the data obtained from the interviews.

\section{Result and Discussion}

The result of the research revealed that primary school teachers prepared for the children usually presented the problems with unknown results more and they ignored the other kinds of problems. Primary school teachers prepared for the children usually presented joining and separation problems with unknown results. Primary school teachers prepared for the children 
usually presented part-part-whole problems with one-part unknown results. Primary school teachers prepared for the children usually presented compare problems with difference unknown results. In other words, it can be said that the teachers are more focused on the unknown problems.

Primary school teachers prepared for the children usually presented multiplication and division problems with Repeated-Addition, equal sharing, repeated-subtraction. In general, while teachers present problems with multiplication and division of children in mathematical activities, the problem types do not equate to all of them.

Primary school teachers; they have expressed various opinions about how they decided on the types of verbal problems and why they put forward the types of problems that they stated while teaching the students to add, subtract, multiply and divide. The vast majority of teachers have stated that children are offered verbal problem types considering the developmental characteristics of children. The reasons for not giving some types of problems are mostly due to the fact that they are not suitable for their developmental characteristics and ages and they are not included in the curriculum achievements. But it contradicts the studies (Carpenter, Carey \& Kouba, 1990; Sarama \& Clements, 2009) of teachers who say that "some types of problems are not appropriate for the development of children" can solve many problems related to numbers even before learning the operational mathematics of children of thought. 
EK-1

SÖZEL PROBLEM TÜRLERİ ANKET FORMU

1.Öğrencilere toplama ve çıkarma türü işlemler öğretirken, aşağıdaki sözel problem türlerinden hangilerine yer verdiyseniz başındaki kutucuğu lütfen işaretleyiniz.

\section{Birleştirme Problem Türü}

( ) Burak'ın 6 tane elması vardır. Alpsu kendisine 4 tane daha verdi. Burak'ın toplamda kaç elması vardır? (Sonuç miktarının bilinmediği durumlar) $6+4=$ ?

( ) Burcu'nun 5 tane şekeri vardır. Annesi ona biraz daha şeker verdi. Burcu'nun şimdi toplam 12 tane şekeri oldu. Buna göre annesi Burcu'ya kaç tane şeker verdi? (Değişim miktarının bilinmediği durumlar) $5+?=12$

( ) Arda'nın birkaç tane kalemi vardır. Babası ona 7 tane kalem daha verdi. Arda'nın şimdi toplam 9 kalemi olduğuna göre Arda'nın başlangıçta kaç tane kalemi vardı?(Başlangıç miktarının bilinmediği durumlar) ?+7=9

\section{Ayırma Problem Türü}

( ) Ege'nin 8 tane kitabı vardır. 4 tanesini arkadaşına verdi. Buna göre Ege'nin kaç tane kitabı kaldı? (Sonuç miktarının bilinmediği durumlar) 8-4=?

( ) Berke'nin 15 tane eriği vardır. Berke eriklerinin birkaç tanesini yedi. Berke'nin bu durumda elinde 6 tane eriği kaldı. Buna göre Berke kaç tane erik yedi? (Değişim miktarının bilinmediği durumlar) 15-?=6

( ) Kumsal'ın birkaç tane bademi vardır. Bademlerinin 7 tanesini annesine verdi. Kumsal'ın 5 tane bademi kaldığına göre başlangıçta kaç tane bademi vardı? (Başlangıç miktarının bilinmediği durumlar) ?-7=5

6.Öğrencilere çarpma ve bölme türü işlemler öğretirken, aşağıdaki sözel problem türlerinden hangilerine yer verdiyseniz başındaki kutucuğu lütfen işaretleyiniz.

\section{Eş - Grup Problemleri (Çarpma)}

( ) Burak'ın 4 poşet portakalı vardır. Her poşette 5 tane elma vardır. Burak'ın toplamda kaç tane elması vardır? (Bütünün bilinmediği durumlar - Tekrarlı toplama)

( ) Bir top dondurmanın fiyatı 5 TL ise 3 top dondurmanın fiyatı kaç TL'dir? (Bütünün bilinmediği durumlar - Oran)

\section{Eş - Grup Problemleri (Parçalamalı Bölme)}

( ) Ege'nin 24 tane kalemi vardır. Bunları 4 arkadaşı arasında eşit olarak paylaştırmak istiyor. Her bir arkadaşı kaç tane kalem alır? (Grup büyüklügünün bilinmediği durumlar - Adil paylaşım)

( ) Berke 5 defter için 25 TL ödemiştir. Buna göre bir defterin fiyatı kaç TL'dir? (Grup büyüklüğünün bilinmediği durumlar - Oran)

\section{Karşılaştırma Problemleri (Çarpma)}

( ) Burak 6 tane elma almıştır. Gizem ise Burak'ın 2 katı elma almıştır. Buna göre Gizem kaç elma almıştır? (Çarpımın bilinmediği durumlar)

\section{EK-2}

\section{GÖRÜŞ ALMA FORMU}

1.Öğrencilere toplama, çıkarma, çarpma ve bölme işlemlerini öğretirken, hangi problem türlerine yer vermeniz gerektiğine nasıl karar veriyorsunuz?

3.Eğer yukarıdaki problem türlerinden bazılarına yer vermiyorsanız neden yer vermiyorsunuz? 